\title{
Further Characterization of Achromobacter nematophilus from American and Soviet Populations of the Nematode Neoaplectana carpocapsae Weiser
}

\author{
GEORGE O. POINAR, JR., G. M. THOMAS, \\ G. V. VEREMTSCHUK, 1 and D. E. PINNOCK \\ Department of Entomology and Parasitology, \\ University of California, Berkeley, California 94720
}

\begin{abstract}
Cultural and biochemical studies showed no significant differences between a bacterium isolated from the nematode Neoaplectana carpocapsae in the Soviet Union and the bacterium, originally described as Achromobacter nematophilus, isolated from the DD-136 strain of $N$. carpocapsae in the United States. Further characterization of A. nematophilus is presented, but its reallocation to a more suitable genus should await the reorganization of the families Achromobacteraceae and Enterobacteriaceae now in progress.
\end{abstract}

The bacterium Achromobacter nematophilus was originally isolated from the intestine of the DD-136 strain of the nematode Neoaplectana carpocapsae Weiser (6-8). Further studies demonstrated the importance of $A$. nematophilus in the development and reproduction of this entomogeneous nematode (9).

It was of interest to know if other neoaplectanid nematodes or geographical populations of the same species had formed associations with identical or related bacteria. Besides being of interest to nematode taxonomists, who could characterize each neoaplectanid nematode by its specific associated bacterium, such findings would also be helpful in understanding the evolutionary development of this genus of nematodes.

By using the technique described by Poinar (6), a specific bacterium was isolated from a new strain of $N$. carpocapsae Weiser obtained from the Soviet Union, and detailed studies were made comparing this bacterium with the original $A$. nematophilus isolated from the DD-136 strain of this nematode in the United States. The results of these studies, along with a supplementary description of $A$. nematophilus, are presented here.

\footnotetext{
1 Present address: All-Union Institute of Plant Protection, Leningrad, USSR.
}

\section{MATERIALS AND METHODS}

A freeze-dried culture of $A$. nematophilus Poinar and Thomas (8) obtained directly from the DD-136 strain of $N$. carpocapsae Weiser at the University of California was used and will be referred to as the DD-136 strain of $A$. nematophilus. From the Soviet Union, a similar bacterium was isolated from a neoaplectanid nematode collected from the body cavity of an elaterid beetle, Agriotes lineatus L., near Leningrad. Although originally thought to be a different nematode (11), breeding tests showed that the Soviet neoaplectanid could interbreed with the DD-136 strain of $N$. carpocapsae and that they belonged to the same species. The Soviet nematode has been referred to as the "agriotos strain" of $N$. carpocapsae Weiser (Poinar and Veremtschuk, Zoolog. $\mathrm{Z}$., in press), and the bacterial isolate from this nematode will be referred to as the "agriotos strain."

Bacterial colonies from both sources were incubated at room temperature $(24 \mathrm{C})$ for determining their biological and cultural characteristics. Measurements of cells were made with 24-hr peptone-water (P-HOH) shake cultures, consisting of $1 \%$ peptone and $0.5 \% \mathrm{NaC} 1$. Colony characteristics were made on 24-hr nutrient agar (NA) cultures and on 1- to 7-day Tergitol-7 agar cultures with TTC (T-7 + TTC). Tergitol-7 agar (3) consists of $5 \mathrm{~g}$ of peptone, $3 \mathrm{~g}$ of yeast extract, $10 \mathrm{~g}$ of lactose, $15 \mathrm{~g}$ of agar, $0.1 \mathrm{ml}$ of Tergitol-7, and $0.025 \mathrm{~g}$ of bromothymol blue per liter. The TTC (triphenyltetrazolium chloride) is added to the Tergitol-7 agar at the rate of $40 \mathrm{mg} / \mathrm{liter}$. $A$. nematophilus is unique in forming blue colonies on a light-blue background on this medium, and this reaction can be used as a diagnostic character for this 
bacterium. Motility broth consisted of $18.5 \mathrm{~g}$ of Brain Heart Infusion plus $5.0 \mathrm{~g}$ of glucose per liter of water and was incubated for $18 \mathrm{hr}$. Leifson's method (5) was used to determine flagellation. Potato slants were prepared by the method of Collins (1). Catalase activity was determined by flooding colonies on NA with $10 \%$ hydrogen peroxide, and oxidase activity was checked by flooding colonies on NA with $1 \%$ aqueous tetramethyl- $p$-phenylenediaminedihydrochloride plus $0.1 \%$ ascorbic acid. Cytochrome oxidase activity was tested by using Schaefer's method (10). Methods involving the use of the following tests were obtained from the 9 th edition of the Difco Manual (3) and Difco Supplementary Literature (4): AC medium, litmus milk, Leoffler's blood serum, gelatin liquefaction, MacConkey agar, Triple Sugar Iron agar (TSI), lysine decarboxylase, Simmon's citrate, phenylalanine deaminase, indole production, nitrate reduction, methyl red and Voges-Proskauer tests. Tests utilizing Hugh and Leifson's oxidation-fermentation medium and arginine dihydrolase and lysine and ornithine decarboxylases, after M $\varnothing$ llers method, were described by Cowan and Steel (2). Anaerobic cultures were grown in a Torbal model AJ-2 jar filled with hydrogen. Measurements of individual cells were made by examining 50 randomly selected rods and spheres, respectively, of both strains.

Fermentation studies were conducted with $1 \%$ of each test sugar in $\mathrm{P}-\mathrm{HOH}$ adjusted to $p \mathrm{H} 7.0$ with $\mathrm{NaOH}$. Two indicators were used: bromothymol blue, sensitive to slight acid changes in $\mathrm{pH}$; and bromocresol purple, sensitive to stronger acidity. By using a double check on fermentative activity, reversals in the $p \mathrm{H}$ of weakly buffered solutions could be detected. These tests, with appropriate controls, were checked every $24 \mathrm{hr}$ for 7 days.

Growth requirements were studied in $24-\mathrm{hr}$ P-HOH cultures, and growth was measured by comparing absorption of the test culture to that of a sterile blank made by using a Bausch \& Lomb Spectronic 20 colorimeter-spectrophotometer, at a wavelength of $600 \mathrm{~nm}$. Temperature tolerance was studied in $\mathrm{P}-\mathrm{HOH}$

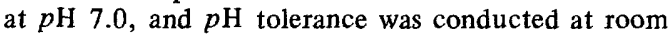
temperature in shake cultures of P-HOH. Sodium chloride tolerance was also conducted in $\mathrm{P}-\mathrm{HOH}$ shake cultures at room temperature.

\section{RESULTS}

Results of the cultural and biological studies are summarized in Table 1. Bacteria from both sources were almost identical under the conditions of these experiments. The cells were large, thick, motile, gram-negative, nonsporeforming rods, occurring singly, in pairs, and rarely forming longer chains. In older cultures, spherical cells were formed, resulting from a disintegration of the cell wall.

On NA, the colonies were about $1 \mathrm{~mm}$ in diameter, greyish-white, convex, circular, with slightly irregular margins, and exhibiting a somewhat rough, granular appearance.

On T-7 + TTC medium, young colonies (less than $30 \mathrm{hr}$ ) may be grey, but then rapidly turn blue, becoming darker with age and developing deep red to maroon centers. The reaction is alkaline and the background turns blue; with 3to 5-day-old cultures, the bromothymol blue becomes absorbed by the cells, leaving clear zones in the agar around the colonies.

The average lengths of bacterial cells from both strains were similar and ranged from about 1 to $6 \mu \mathrm{m}$. Both strains had peritrichous flagellation. Neither strain produced pigment on NA, in $\mathrm{P}-\mathrm{HOH}$, or on potato; however, both produced a brown pigment on Leoffler's blood serum. Both strains were aerobic in AC medium, and reached depths of $12 \mathrm{~mm}$ and 18 $\mathrm{mm}$, respectively. Curd in litmus milk was produced by both strains, which also were able to liquefy gelatin. The strains were negative for the following enzymes: catalase, oxidase, cytochrome oxidase, arginine dihydrolase, lysine and ornithine decarboxylases, and phenylalanine deaminase. Neither strain utilized citrate, produced indole, or reduced nitrate to nitrite. Both were negative for the methyl red and Voges-Proskauer tests. Hugh and Leifson's O-F medium showed both strains to be fermentative in their metabolism of glucose. Some growth of both strains was obtained in the Torbal anaerobic jar after 4 days on NA.

On the basis of these results, we will expand on the original characteristics presented for $A$. nematophilus (8). In the present studies, good growth was obtained on MacConkey agar at room temperature in $24 \mathrm{hr}$, whereas, in the original description, little or no growth was reported at $37 \mathrm{C}$ for 3 to 7 days. Again, good growth on potato was obtained at room temperature in the present studies in contrast to the original report of no growth at $30 \mathrm{C}$. An acid reaction was reported on TSI at $20 \mathrm{C}$ in the original description, but the same test in the present investigation at room temperature was neutral. These differences point out the importance of running tests at optimum temperature for the organisms.

All of the 19 carbohydrates tested in the fermentation studies were weakly positive. Positive results were obtained by using weakly buffered solutions with adonitol, dulcitol, lactose, mannitol, rhamnose, salicin, sorbose, and sucrose, all of which were recorded as negative in the original description of $A$. nematophilus. Some of the sugars giving positive results were tested for the first time. These include esculin, melezitose, melibiose, raffinose, and saccharose.

The results of the studies on tolerance to environmental conditions are recorded in Table 2. The temperature tolerance study showed 
TABLE 1. Cultural and biological characteristics of the DD-136 and Agriotos strains of Achromobacter nematophilus isolated from separate populations of Neoaplectana carpocapsae

\begin{tabular}{|c|c|c|}
\hline \multirow[b]{2}{*}{ Test (room temp $=24 \mathrm{C}$ ) } & \multicolumn{2}{|c|}{ Bacterial strains $a$} \\
\hline & DD-136 strain & Agriotos strain \\
\hline \multicolumn{3}{|l|}{ Cell size (P-HOH; $24 \mathrm{hr})$} \\
\hline Rods (avg length $\times$ width) $\ldots \ldots \ldots \ldots \ldots \ldots$ & $5.4 \times 1.1 \mu \mathrm{m}$ & $5.0 \times 1.1 \mu \mathrm{m}$ \\
\hline Spheres (avg diameter) . . . . . . . . . . . . . . & $2.5 \mu \mathrm{m}$ & $2.4 \mu \mathrm{m}$ \\
\hline 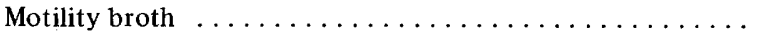 & + & + \\
\hline 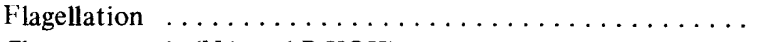 & Peritrichous & Peritrichous \\
\hline Chromogenesis (NA and $\mathrm{P}-\mathrm{HOH}) \ldots \ldots \ldots \ldots$ & - & - \\
\hline 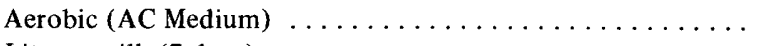 & + & + \\
\hline Litmus milk (7 days) $\ldots \ldots \ldots \ldots \ldots \ldots \ldots \ldots$ & + & + \\
\hline Reduction peptonization $\ldots \ldots \ldots \ldots \ldots \ldots$ & + & + \\
\hline 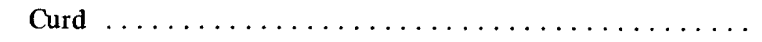 & + & + \\
\hline \multicolumn{3}{|l|}{ Loeffler's blood serum ( 5 days) } \\
\hline 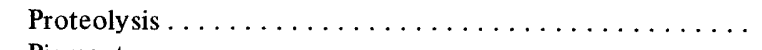 & + & + \\
\hline 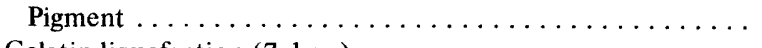 & Light brown & Light brown \\
\hline 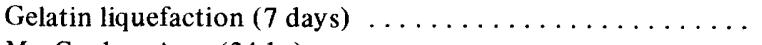 & + & + \\
\hline 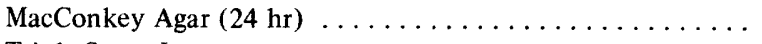 & $+w$ & + \\
\hline 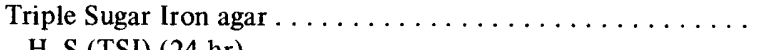 & $\mathrm{NC}, \mathrm{NC},-$ & $\mathrm{NC}, \mathrm{NC},-$ \\
\hline 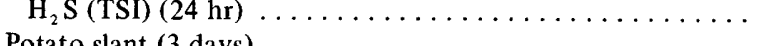 & - & - \\
\hline \multicolumn{3}{|l|}{ Potato slant ( 3 days) } \\
\hline 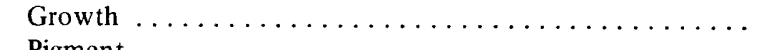 & + & + \\
\hline 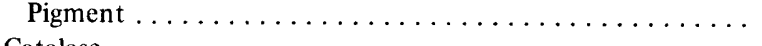 & - & - \\
\hline 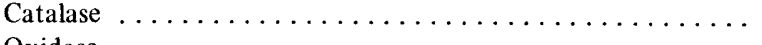 & - & - \\
\hline 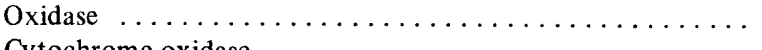 & - & - \\
\hline Cytochrome oxidase $\ldots \ldots \ldots \ldots \ldots \ldots \ldots \ldots$ & - & - \\
\hline Lysine decarboxylase $\ldots \ldots \ldots \ldots \ldots \ldots \ldots \ldots \ldots \ldots \ldots \ldots \ldots \ldots \ldots$ & - & - \\
\hline Arginine dihydrolase $\ldots \ldots \ldots \ldots \ldots \ldots \ldots \ldots \ldots \ldots \ldots \ldots \ldots \ldots$ & - & - \\
\hline 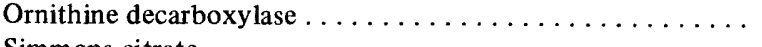 & - & - \\
\hline 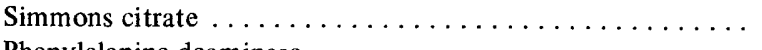 & - & - \\
\hline Phenylalanine deaminase $\ldots \ldots \ldots \ldots \ldots \ldots \ldots$ & - & - \\
\hline Indole production $\ldots \ldots \ldots \ldots \ldots \ldots \ldots \ldots \ldots \ldots \ldots \ldots \ldots \ldots \ldots \ldots$ & - & - \\
\hline Nitrate reduction $\ldots \ldots \ldots \ldots \ldots \ldots \ldots \ldots \ldots \ldots \ldots \ldots \ldots \ldots \ldots$ & - & - \\
\hline 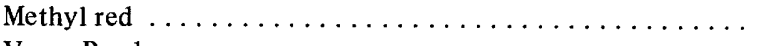 & - & - \\
\hline Voges-Proskauer ......................... & - & - \\
\hline \multirow{2}{*}{\multicolumn{3}{|c|}{$\begin{array}{l}\text { Hugh and Leifson's oxidation- } \\
\text { fermentation medium } \\
\text { Open tube } \ldots \ldots \ldots \ldots \ldots \ldots \ldots \ldots \ldots \ldots \ldots \ldots \ldots\end{array}$}} \\
\hline & & + \\
\hline 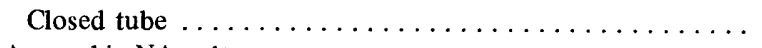 & + & + \\
\hline & $+\mathrm{w}$ & $+w$ \\
\hline Fermentations: $(24 \mathrm{hr})$ & Bt.B.:B.C.P. & Bt.B:B.C.P. \\
\hline$\ldots \ldots \ldots \ldots \ldots \ldots \ldots \ldots \ldots$ & $+w:-$ & $+:-$ \\
\hline$\ldots \ldots \ldots \ldots \ldots \ldots \ldots \ldots$ & $+:-$ & $+:-$ \\
\hline 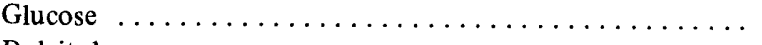 & $+:+$ & $+:+$ \\
\hline 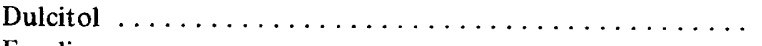 & $+w:+w$ & $+w:+w$ \\
\hline 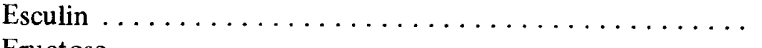 & $-:+w$ & $-:+w$ \\
\hline 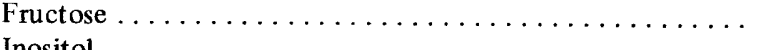 & $+w:+w$ & $+w:+w$ \\
\hline 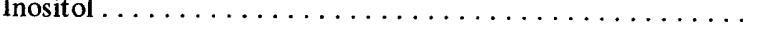 & $+w:+w$ & $+w:+w$ \\
\hline
\end{tabular}


TABLE 1. Cultural and biological characteristics of the DD-136 and Agriotos strains of Achromobacter nematophilus isolated from separate populations of Neoaplectana carpocapsae (Con't.)

\begin{tabular}{|c|c|c|}
\hline Fermentations: $(24 \mathrm{hr})$ & Bt.B:B.C.P. & Bt.B.:B.C.P. \\
\hline 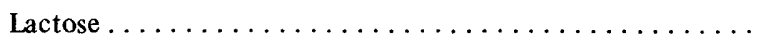 & $+w:+w$ & $+w:+w$ \\
\hline 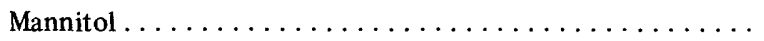 & $+w:+w$ & $+w:+w$ \\
\hline 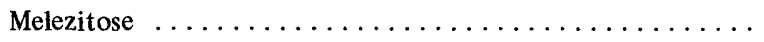 & $+w:+w$ & $+w:+w$ \\
\hline 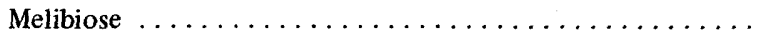 & $+w:+w$ & $+w:+w$ \\
\hline 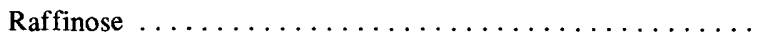 & $+w:+w$ & $+w:+w$ \\
\hline 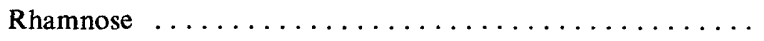 & $+w:+w$ & $+w:+w$ \\
\hline 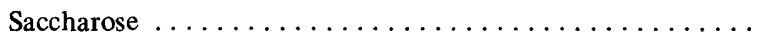 & $+w:+w$ & $+w:+w$ \\
\hline 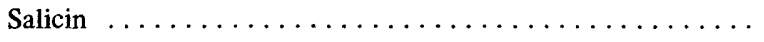 & $+w:+w$ & $+w:+w$ \\
\hline 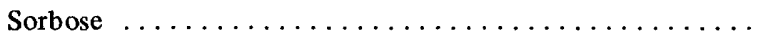 & $+w:+w$ & $+w:+w$ \\
\hline 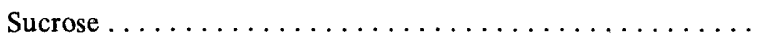 & $+w:+w$ & $+w:+w$ \\
\hline 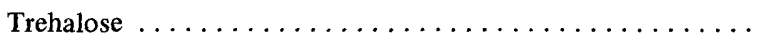 & $+:+w$ & $+:+w$ \\
\hline 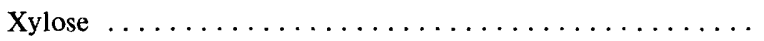 & $+w:+w$ & $+w:+w$ \\
\hline
\end{tabular}

a Symbols and abbreviations: -, negative; +, positive; +w, weakly positive; NC, no change; Bt.B., Bromothymol blue indicator; B.C.P., bromocresol purple indicator.

TABLE 2. Growth studies of the Agriotos and DD-136 strains of Achromobacter nematophilus under varying conditions of temperature, $p H$, and salt concentration

\begin{tabular}{|c|c|c|c|c|}
\hline & & \multicolumn{3}{|c|}{ Absorption of bacterial strains ${ }^{a}$} \\
\hline \multicolumn{2}{|c|}{ Conditions studied } & DD-136 strain & Agriotos strain & Control \\
\hline Temp tolerance & $C$ & & & \\
\hline$p \mathrm{H} 7$ & 10 & 1 & 1 & 0 \\
\hline \multirow[t]{4}{*}{$0.5 \% \mathrm{NaCl}$} & 24 & 6 & 5 & 0 \\
\hline & 30 & 14 & 10 & 0 \\
\hline & 37 & 1 & 1 & 0 \\
\hline & 42 & 0 & 0 & 0 \\
\hline$p H$ tolerance & $p H$ & & & \\
\hline $24 \mathrm{C}$ & 5.0 & 0 & 0 & 0 \\
\hline \multirow[t]{5}{*}{$0.5 \% \mathrm{NaC} 1$} & 6.0 & 0 & 0 & 0 \\
\hline & 7.1 & 69 & 4 & 0 \\
\hline & 8.2 & 57 & 2 & 0 \\
\hline & 9.0 & 31 & 3 & 0 \\
\hline & 10.0 & 0 & 0 & 0 \\
\hline $\begin{array}{c}\text { Sodium chloride } \\
\text { tolerance }\end{array}$ & $\begin{array}{c}\text { Per cent concn } \\
\text { of } \mathrm{NaCl}\end{array}$ & & & \\
\hline $24 \mathrm{C}$ & 0.0 & 0 & 0 & 0 \\
\hline \multirow{5}{*}{$p \mathrm{H} 7$} & 0.5 & 90 & 67 & 0 \\
\hline & 1.0 & 82 & 62 & 0 \\
\hline & 3.0 & 1 & 1 & 0 \\
\hline & 4.0 & 0 & 1 & 0 \\
\hline & 5.0 & 0 & 1 & 0 \\
\hline
\end{tabular}

$a$ Growth expressed as per cent absorbance in $24 \mathrm{hr}$. P-HOH culture, measured in a Bausch \& Lomb Spectronic 20 colorimeter-spectrophotometer, at a wavelength of $600 \mathrm{~nm}$. A reading of 1 on the Spectronic 20 is considered equivalent to 0 for the purposes of this study. 
that both strains reached a growth peak at $30 \mathrm{C}$.

The results of the $p \mathrm{H}$ study showed best growth for both strains at $p \mathrm{H} \mathrm{7.1.} \mathrm{No} \mathrm{growth}$ occurred below $p \mathrm{H} 6.0$ nor above $p \mathrm{H} 10.0$.

Both strains showed the same tolerance for sodium chloride, reaching a growth peak at $0.5 \%$ and showing good growth at $1.0 \%$. There was little or no growth above $3.0 \%$.

\section{DISCUSSION}

These studies show no significant differences between the bacterium isolated from a strain of $N$. carpocapsae in the Soviet Union and $A$. nematophilus isolated from the DD-136 strain of $N$. carpocapsae from the United States and, for all taxonomic and biological purposes, they may be considered the same species.

It is possible that the members of the Achromobacteraceae will be characterized as being strict aerobes (A. J. Holding, personal communication), and, if this is the case, our tests showing that $A$. nematophilus is capable of anaerobic development may remove this species from the genus Achromobacter. Thus, $A$. nematophilus may eventually be shifted into the family Enterobacteriaceae, although the negative catalase reaction might restrict its placement somewhat.

Serological tests comparing antisera of $A$. nematophilus with various bacteria from the families Achromobacteraceae and Enterobacteriaceae are now in progress and will be reported at a later date.

Since the diagnostic characters of many of the existing genera in Achromobacteraceae and Enterobacteriaceae will most likely be changed with the new edition of Bergy's Manual, assignment of $A$. nematophilus to another genus would be premature at this time.

\section{LITERATURE CITED}

1. Collins, C. H. 1967. Microbiological methods, 2nd ed. Plenum Press, New York; Butterworths, London.

2. Cowan, S. T., and K. J. Steel. 1966. Manual for the identification of medical bacteria. Cambridge University Press, New York.

3. Difco Laboratories. 1953. Difco manual of dehydrated culture media and reagents for microbiological and clinical laboratory procedures, 9th ed. Difco Laboratories, Inc., Detroit.

4. Difco Laboratories. 1962. Difco supplementary literature. Difco Laboratories, Inc., Detroit.

5. Leifson, E. 1960. Atlas of bacterial flagellation. Academic Press Inc., New York.

6. Poinar, G. O., Jr. 1966. The presence of Achromobacter nematophilus in the infective stage of a Neoaplectana sp. (Steinernematidae: Nematoda). Nematologica 12:105-108.

7. Poinar, G. O., Jr. 1967. Description and taxonomic position of the DD-136 nematode (Steinernematidae, Rhabditoidea) and its relationship to Neoaplectana carpocapsae Weiser. Proc. Hel. Soc. Wash. 34:199-209.

8. Poinar, G. O., Jr., and G. M. Thomas. 1965. A new bacterium, Achromobacter nematophilus sp. nov. (Achromobacteriaceae: Eubacteriales) associated with a nematode. Int. Bull. Bacteriol. Nomencl. Taxon. 15:249-252.

9. Poinar, G. O., Jr., and G. M. Thomas. 1966. Significance of Achromobacter nematophilus Poinar and Thomas (Achromobacteriaceae: Eubacteriales) in the development of the nematode, DD-136 (Neoaplectana sp. Steinernematidae). Parasitology 56:385-390.

10. Schaefer, E. 1961. Application of the cytochrome oxidase reaction to the detection of Pseudomonas aeruginosa in mixed cultures. Roentgen Univ. Lab. Praxis 14:142-146.

11. Veremtschuk, G. V. 1969. A new species of entomopathogenic nematode of the genus Neoaplectana (Rhabditida: Steinernematidae). Parasitologia 3:249-252 (in Russian). 